\title{
In-vitro ANTI-INFLAMMATORY AND ANTI-ARTHRITIC ACTIVITY OF ETHANOLIC EXTRACT OF Hibiscus rosa sinensis LEAVES
}

\author{
Talapudi Sruthi ${ }^{1}$, Chinta Koteswara Rao ${ }^{2}$, R.A. Zerubabel Michael ${ }^{3}$, \\ S. Monica Nissy ${ }^{1}$ and D. V. Surya Prakash, ${ }^{4}$ 冈 \\ ${ }^{1}$ Research Scholar, Department of Chemical Engineering, Andhra University, Visakhapatnam- \\ 530003, Andhra Pradesh, India. \\ ${ }^{2}$ Data Processing officer, A.P.State Biodiversity Board, Guntur-522508, Andhra Pradesh, India. \\ ${ }^{3}$ Research Scientist, Department of Chemical Engineering, Andhra University, Visakhapatnam- \\ 530003, Andhra Pradesh, India. \\ ${ }^{4}$ Assistant Professor, Department of Biotechnology, Meerut Institute of Engineering and \\ Technology (MIET), Meerut-250005, UP, India. \\ ${ }^{\square}$ Corresponding Author: prakashsurya55@gmail.com
}

\begin{abstract}
Hibiscus is a genus of a gorgeous flowering potted plant. Hibisceae tribe is one of the ornamental plants that are most commonly available and it belonging to Malvaceae family is Hibiscus rosa-sinensis. The purpose of this work is to evaluate the in-vitro anti-athritic effect of Hibiscus rosa sinensis at various levels of concentration. Here the percentage of membrane stabilization was carried out at various concentrations for ethanolic extract and Diclofenac sodium. Hibiscus extract was found to have maximum membrane stabilization of $94.97 \%$ at $500 \mu \mathrm{g} / \mathrm{ml}$. The highest percentage inhibition of denaturation of protein and membrane stabilization for these plant extracts were found to be $89.45 \%$ and $91.09 \%$ at a dose of $500 \mu \mathrm{g} / \mathrm{ml}$. Our research studies support the isolation and the use of active phytochemicals of hibiscus in the treatment of inflammation and arthritis.

Keywords: Hibiscus rosa sinensis, Anti-inflammatory, Anti-arthritic, Human Red Blood Cell (HRBC), Protein Denaturation.
\end{abstract}

RASĀYAN J. Chem., Vol. 14, No.4, 2021

\section{INTRODUCTION}

Hibiscus rosa-sinensis is known as the rose of China, an evergreen herbaceous plant in certain markets. It is a tropical Hibiscus plant, known as, Shoeblack herb or Chinese Hibiscus and is a Chinese native that is now widely cultivated as an ornamental in the tropical and subtropical regions. It possesses dark-red, large, ornamental flower. Hibiscus leaves, roots and flowers are anodyne, emmenagogue and stimulate blood circulation and regulate menstruation. ${ }^{1}$ Traditionally, flower extract is used for high blood pressure, liver disorder and as an aphrodisiac. Young flowers and leaves are used for headaches also. Hibiscus tea is rich in vitamin C. The leaves and flowers are used to extract the juice that is used for many years to treat some diseases, painful symptoms and herbal cosmetics. It has been reported that Hibiscus flowers are having antitumor, anti-inflammatory ${ }^{2}$, anti-asthmatic, antipyretic, analgesic properties. Also, antimicrobial, anti-fungal, anti-oxidant properties are present in the flowers of Hibiscus rosa-sinensis that are proved by several studies. The photochemical components which are extracted from flowers, leaves, roots and stems from Hibiscus have shown beneficial effects for human health such as anti-oxidant property, which is the prevention of free radicals that can damage deoxyribonucleic acid. In several tropical countries, this plant is showing several important medicinal uses to treat gastric ulcers, hair loss, infections caused by bacteria and fungi, diabetes, fever, cough ${ }^{3}$, inflammation, and wounds. Studies on toxicity showed according to histological analysis, there were no signs of toxicity at higher doses in extracts from this plant. Photochemical analysis showed that alkaloids, saponins, terpenoids, tannins, 
RASĀYAN J. Chem.

Vol. 14 | No. 4 |2279-2284| October- December | 2021

flavonoids which are the main bioactive phytocompounds are responsible for its therapeutic effects. ${ }^{4}$ Various studies have shown that Hibiscus flower and leaf extract has opted for nanoparticles synthesis due to the existence of phenolic hydroxyl groups that serve as natural reducing agents.

\section{Collection of Plant Material}

\section{EXPERIMENTAL}

The hibiscus leaves were collected from Visakhapatnam city, Andhra Pradesh, India. The leaves were dried under sunlight, powdered and sieved with 150 mesh size. ${ }^{5}$

\section{Preparation of Extract}

$10 \mathrm{gm}$ of dried leaves powder was extracted with ethanol using a soxhlet extractor for $5 \mathrm{hr}$. After this process, the ethanol solvent was distilled at a low-temperature level point of water bath ${ }^{6}$ then finally we get the crude extract.

\section{Preparation of HRBC Suspension}

HRBC is a Human Red Blood Cells. In this research, Alsever's sterilized solution is prepared with $0.8 \%$ sodium citrate $\left(\mathrm{Na}_{3} \mathrm{C}_{6} \mathrm{H}_{5} \mathrm{O}_{7}\right), 0.42 \%$ sodium chloride $(\mathrm{Nacl}), 2 \%$ dextrose and $0.05 \%$ citric acid $\left(\mathrm{C}_{6} \mathrm{H}_{8} \mathrm{O}_{7}\right)$ in water. Now this sample was combined with an equal volume level of human blood. Then the mixedblood sample was centrifuged up to 10-15 minutes at $3000 \mathrm{rpm} .{ }^{7}$ The cells were washed with isosaline up to two to three times. The mixed blood sample volume was measured and reformed as suspension (10\% $\mathrm{v} / \mathrm{v}$ ) with isosaline.

\section{Heat-Induced Hemolysis}

Here hypo tonicity mediated to Human Red Blood cells membrane lysis is the concept involved here. The mixture of assay includes $2 \mathrm{ml}$ hyposaline $(0.36 \%), 1 \mathrm{ml}$ of the buffer of phosphate $(0.15 \mathrm{M})$ at $\mathrm{pH} 7.4$, $0.5 \mathrm{ml}$ of $10 \% \mathrm{v} / \mathrm{v}$ HRBC suspension with $0.5 \mathrm{ml}$ of crude extract and Diclofenac sodium standard drug of different levels of concentrations ( 25 to $500 \mu \mathrm{g} / \mathrm{ml}$ ). Here control is distilled $\mathrm{H}_{2} \mathrm{O}$ to produce hemolysis. ${ }^{8-9}$ Then incubated at $38^{\circ} \mathrm{C}$ for $30 \mathrm{~min}$ and finally centrifuged. The suspension content was observed through UV spectrophotometer at 560nm. The Percentage of hemolysis of Human Red Blood cells membrane calculations:

$$
\text { Percentage of Hemolysis }=(\text { OD of Test solution / OD of Control }) \times 100
$$

The Percentage of Human Red Blood cells membrane stabilization calculations:

$$
\text { Percentage of Protection }=100-[(\text { OD of Test solution / OD of Control }) \text { X 100 }]
$$

\section{Inhibition of Protein Denaturation}

Here Hibiscus extract (test solution) and drug of diclofenac sodium (standard solution) were taken in different concentrations $(25$ to $500 \mu \mathrm{g} / \mathrm{ml})$. These solutions were maintained at $\mathrm{pH} 6.3$ with the aid of $1 \mathrm{~N}$ hydrochloric solution. ${ }^{10}$ Now these solutions were incubated for $15-25 \mathrm{~min}$ at $38^{\circ} \mathrm{c}$. After cooling these solutions, just phosphate buffer $(2.5 \mathrm{ml})$ is added. The OD was observed at $416 \mathrm{~nm}$ by using UVspectrophotometer. Here 100 percentage of protein denaturation is expressed by the control. These experimental results were observed with Standard drugs. The preparations of solutions were reported in Table-1.

Table1: Preparation of Solutions

\begin{tabular}{c|l}
\hline S. No. & \multicolumn{1}{c}{ Preparation of Sample } \\
\hline 1 & Standard solution $(0.5 \mathrm{ml})=5 \% \mathrm{~W} / \mathrm{V}$ of BSA $(0.45 \mathrm{ml})+$ Diclofenac sodium $(0.05 \mathrm{ml})$ \\
\hline 2 & Test solution $(0.5 \mathrm{ml})=5 \% \mathrm{~W} / \mathrm{V}$ of BSA $(0.45 \mathrm{ml})+$ Test solution $(0.05 \mathrm{ml})$ \\
\hline 3 & Product control $(0.5 \mathrm{ml})=$ Distilled water $(0.45 \mathrm{ml})+$ Test solution $(0.05 \mathrm{ml})$ \\
\hline 4 & Test control $(0.5 \mathrm{ml})=5 \% \mathrm{~W} / \mathrm{V}$ of BSA $(0.45 \mathrm{ml})+$ Distilled water $(0.05 \mathrm{ml})$ \\
\hline
\end{tabular}

The percentage inhibitions of denaturation of protein of various concentrations were reported in Table-3 and Fig.-3. The percentage inhibition of denaturation of protein calculations: 
RASĀYAN J. Chem.

Vol. 14 | No. 4 |2279-2284| October- December | 2021

Percentage of Inhibition $=[100-($ OD of Test Solution - OD of Product Control $) \div($ OD of Test Control $)$ $\times 100]$

\section{Effect on Membrane Stabilization / Inhibition of Membrane lysis}

Here hypo tonicity mediated to Human Red Blood cells membrane lysis is the concept involved here. ${ }^{11}$ The mixture of assay includes $2 \mathrm{ml}$ hyposaline $(0.36 \%), 1 \mathrm{ml}$ of the buffer of phosphate $(0.15 \mathrm{M})$ at $\mathrm{pH} 7.4$, $0.5 \mathrm{ml}$ of $10 \% \mathrm{v} / \mathrm{v}$ HRBC suspension with $0.5 \mathrm{ml}$ of crude extract and Diclofenac sodium standard drug of different levels of concentrations ( 25 to $500 \mu \mathrm{g} / \mathrm{ml}$ ). Here control is distilled $\mathrm{H}_{2} \mathrm{O}$ to produce hemolysis. ${ }^{12}$ Then incubated at $38^{\circ} \mathrm{C}$ for $30 \mathrm{~min}$ and finally centrifuged. The suspension content was observed through UVspectrophotometer at $560 \mathrm{~nm}$. The percentage of membrane stabilization at various concentrations was reported in Table-2 and shown in Fig. -4 . The percentage inhibition of membrane stabilization calculation:

$$
\% \text { Inhibition }=100-[(\mathrm{OD} \text { of test solution }) \div(\mathrm{OD} \text { of control }) \times 100]
$$

\section{RESULTS AND DISCUSSION}

HRBC membrane lysis was induced by inhibition of hypotonicity i.e, the anti-inflammatory activity was assayed by HRBC membrane stabilization. ${ }^{13}$ The percentage of membrane stabilization for ethanolic

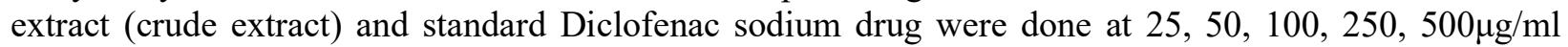
concentrations. Ethanolic extract of Hibiscus are effective in inhibiting HRBC hemolysis ${ }^{14}$ induced by heat at various levels of concentrations $(25-500 \mu \mathrm{g} / \mathrm{ml})$ and it showed in Table-2. The highest inhibition level was shown to be $90.75 \%$ at $500 \mu \mathrm{g} / \mathrm{ml}$. The hemolysis of membrane is reduced with increasing concentrations, as shown in Fig.-1 and membrane stabilization/support is increased as shown in Fig.-2.

Table-2: Effect of Hibiscus Plant Extract and Standard Drug on Membrane Stabilization and Hemolysis of HRBC Membrane

\begin{tabular}{c|c|c|c|c|c}
\hline S.No. & Conc. $(\mu \mathrm{g} / \mathrm{ml})$ & $\begin{array}{c}\text { \% Hemolysis of Hibiscus } \\
\text { rosa sinensis }\end{array}$ & $\begin{array}{c}\text { \% Stabilization } \\
\text { of Hibiscus rosa } \\
\text { sinensis }\end{array}$ & $\begin{array}{c}\% \text { Hemolysis of } \\
\text { Diclofenac } \\
\text { Sodium }\end{array}$ & $\begin{array}{c}\% \text { Stabilization } \\
\text { of Diclofenac } \\
\text { Sodium }\end{array}$ \\
\hline 1 & 25 & 31.26 & 68.52 & 48.17 & 54.72 \\
\hline 2 & 50 & 20.70 & 78.47 & 24.56 & 80.03 \\
\hline 3 & 100 & 17.09 & 84.70 & 18.80 & 89.57 \\
\hline 4 & 250 & 11.67 & 88.64 & 15.78 & 94.60 \\
\hline 5 & 500 & 8.40 & 90.75 & 7.91 & 97.78 \\
\hline
\end{tabular}

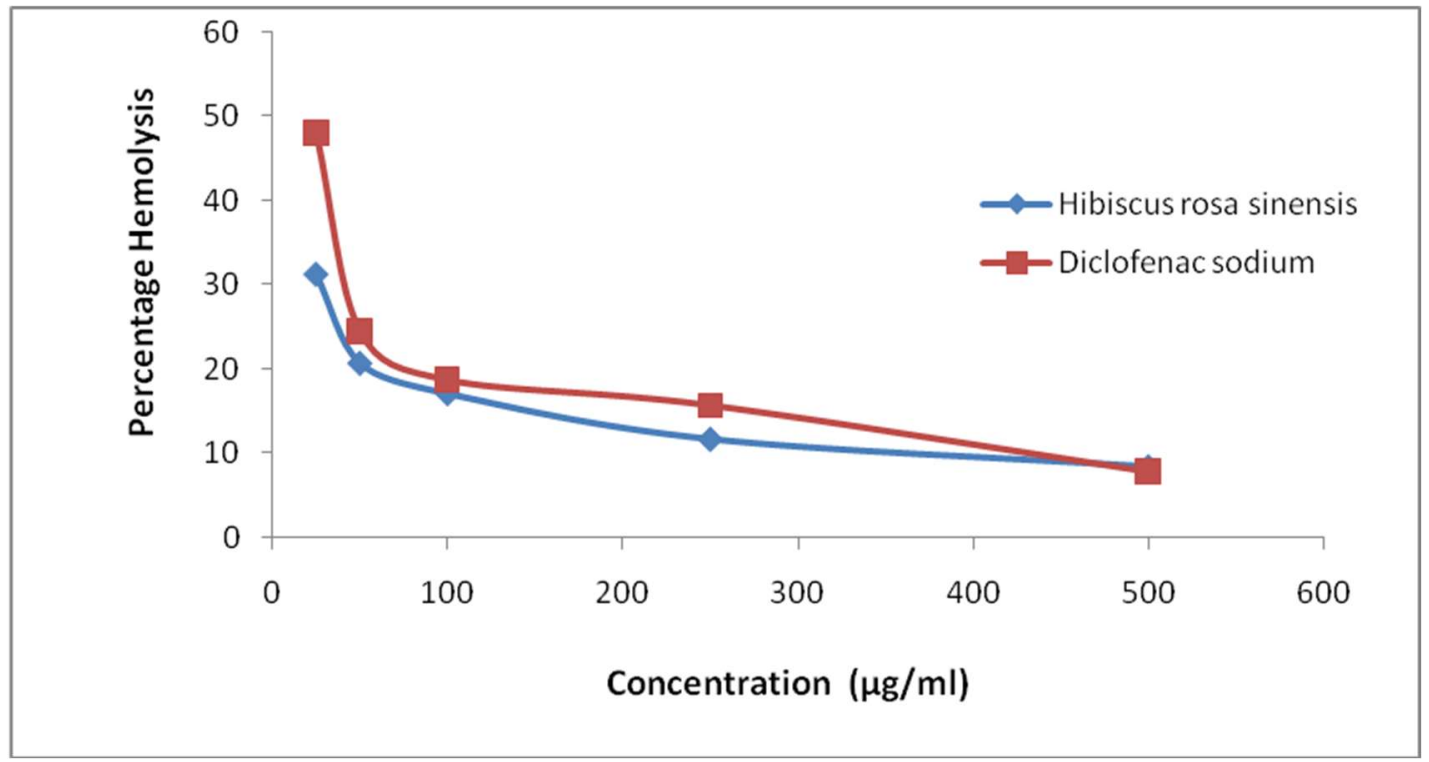

Fig.-1: Effect of Hibiscus Plant Extract on Hemolysis of HRBC Membrane 
RASĀYAN J. Chem.

Vol. 14 | No. 4 |2279-2284| October- December | 2021

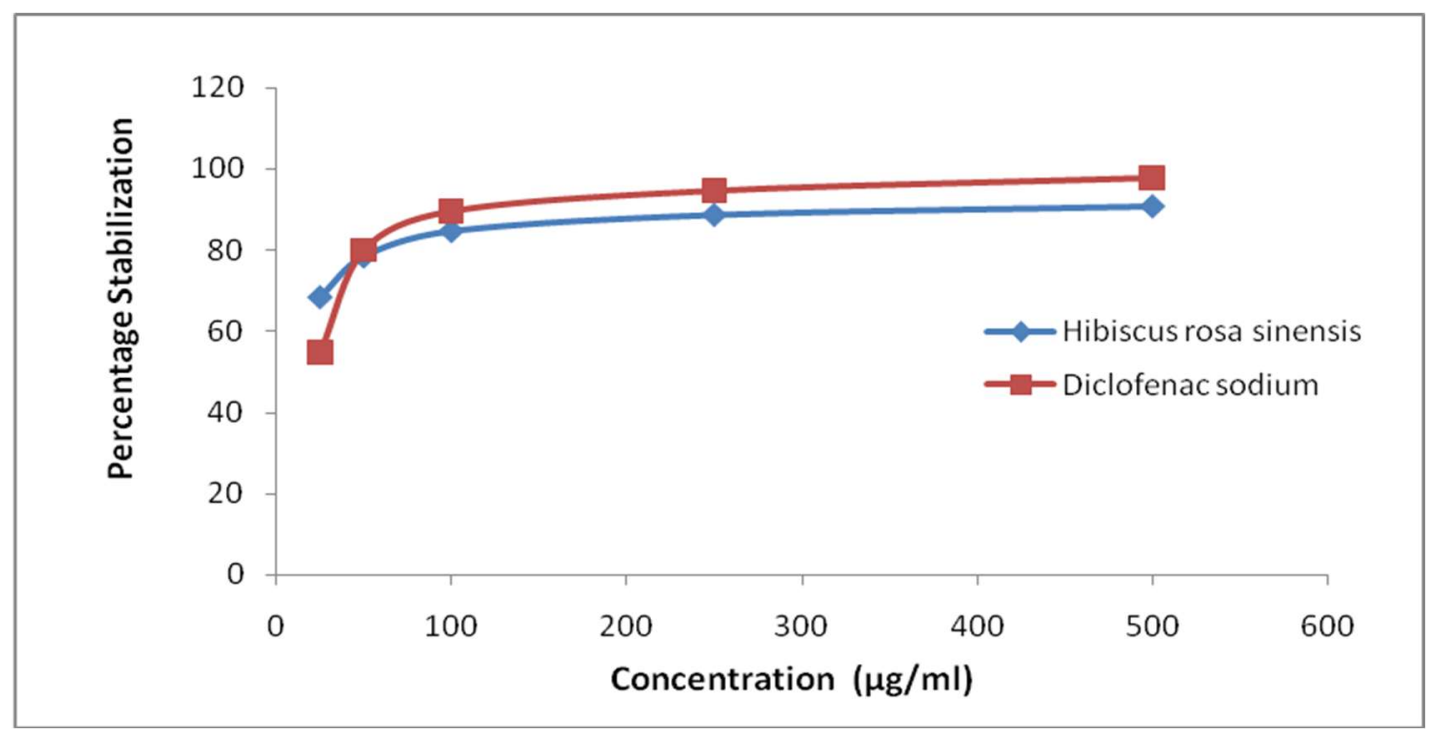

Fig.-2: Effect of Hibiscus Plant Extract on HRBC Membrane Stabilization

At various concentrations, the ethanolic extract of Hibiscus showed substantial activity and its effect was contrasted with standard drug. $89.45 \%$ and $91.09 \%$ were found to be the highest percent inhibition of denaturation of protein ${ }^{15-16}$ and membrane stabilization at $500 \mu \mathrm{g} / \mathrm{ml}$ as shown in Table-3. Auto antigen productions are formed in some arthritic disorders due to denaturation of protein and membrane lysis. From the results (Fig.-3 and 4) of this analysis, that ethanolic extract (Crude extract) can regulate the various autoantigen production ${ }^{17-18}$ and arrested to denaturation of protein and membrane lysis in the arthritic disorder. ${ }^{19-20}$

Table-3: Effect of Hibiscus Plant Extract and Standard Drug on Inhibition of Membrane Stabilization and Denaturation of Protein

\begin{tabular}{c|c|c|c|c|c}
\hline S. No. & Conc. $(\mu \mathrm{g} / \mathrm{ml})$ & $\begin{array}{c}\text { \% inhibition of Hibiscus } \\
\text { Plant Extract }\end{array}$ & $\begin{array}{c}\text { \% inhibition of } \\
\text { Diclofenac } \\
\text { Sodium }\end{array}$ & $\begin{array}{c}\text { \% Stabilization } \\
\text { of Hibiscus Plant } \\
\text { Extract }\end{array}$ & $\begin{array}{c}\text { \% Stabilization } \\
\text { of Diclofenac } \\
\text { Sodium }\end{array}$ \\
\hline 1 & 25 & 61.64 & 65.72 & 66.97 & 58.08 \\
\hline 2 & 50 & 69.30 & 73.68 & 78.54 & 76.00 \\
\hline 3 & 100 & 77.25 & 88.98 & 83.50 & 87.40 \\
\hline 4 & 250 & 84.90 & 93.06 & 89.47 & 92.67 \\
\hline 5 & 500 & 89.45 & 96.81 & 91.09 & 97.88 \\
\hline
\end{tabular}

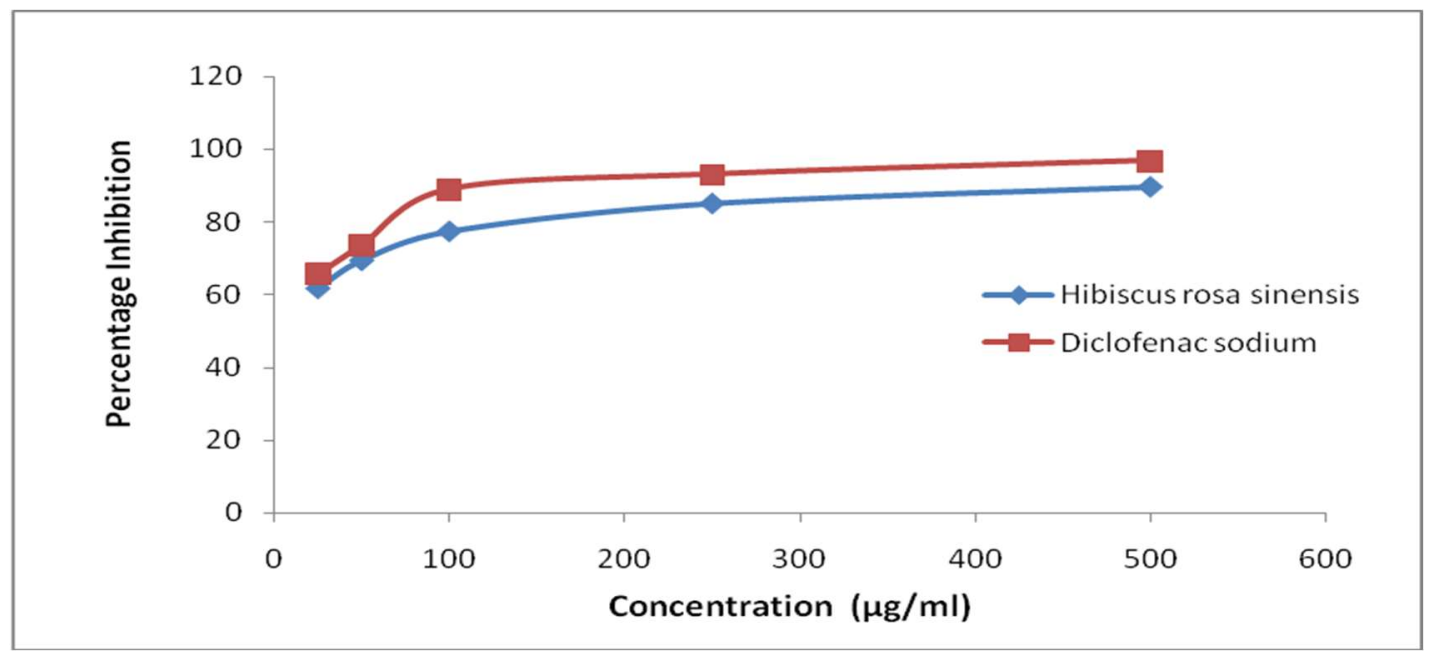

Fig.-3: Effect of Hibiscus Plant Extract on Percentage Inhibition of Denaturation of Protein 


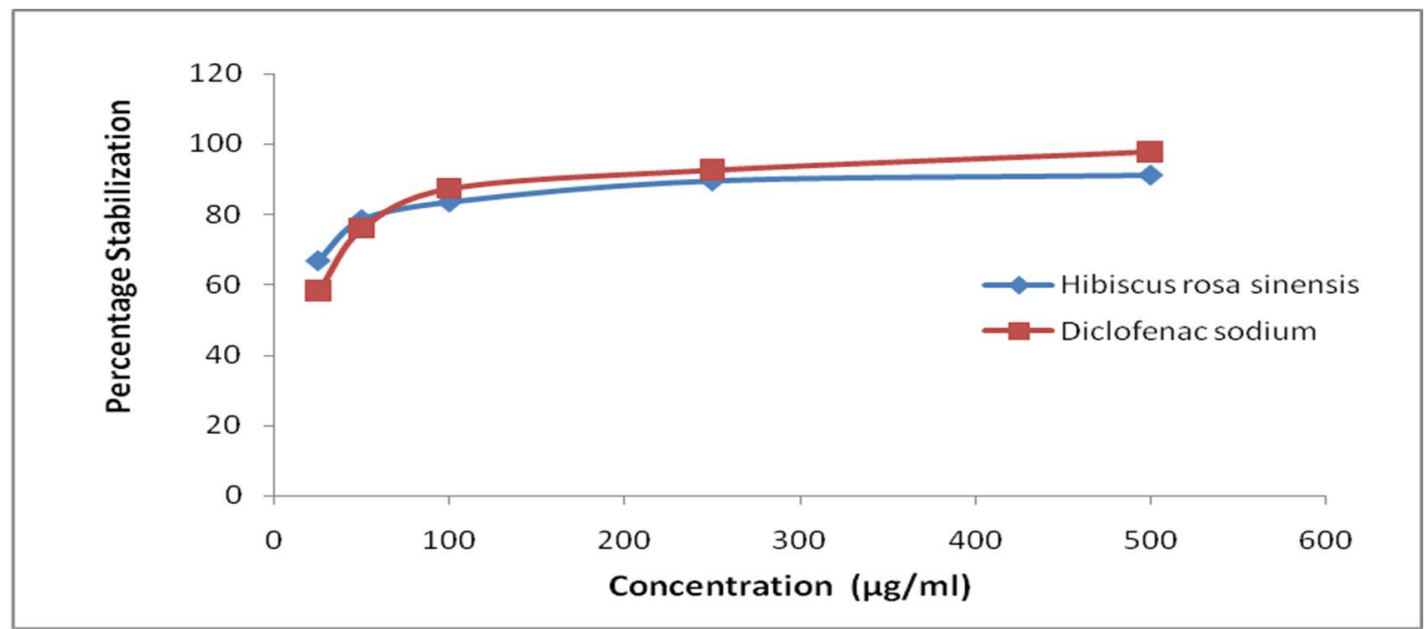

Fig.-4: Effect of Hibiscus Plant Extract on Percentage Membrane Stabilization

CONCLUSION

Here studied to find out the anti-inflammatory activity and anti-arthritic activities of Hibiscus species. Inhibition of denaturation of protein and membrane stabilization was studied to the action of anti-arthritic activity of the Hibiscus plant. This research in-vitro experiment on hibiscus extracts shows the depression of inflammation. Due to the presence of phytochemicals like phenolic acids, phenolic compounds, alkaloids, tannins, saponins, bioflavonoids and polyphenolic compounds are responsible for these activities. Hence, Hibiscus can be used as an effective anti-inflammatory agent.

\section{ACKNOWLEDGMENT}

Thanks to the Department of Biotechnology, MIET Institute, Meerut, Uttar Pradesh State for provided facilities.

\section{REFERENCES}

1. A. Reveendran, S. Varghese, K.Viswanathan, IOSR Journal of Applied Physics, 8(3), 35(2016), https://doi.org/10.9790/4861-0803023538

2. Y.W. Mak, L.O. Chuah, R. Ahmad, R. Bhat, Journal of King Saud University-science, 25(4), 275(2013), https://doi.org/10.1016/j.jksus.2012.12.003

3. L. Kumar, G. Chakraborthy, V. Singh, A. Mazumder, Journal of Advances in Pharmacy and Healthcare Research, 2(4), 9(2012).

4. A. Missoum, Journal of Ayurvedic and Herbal Medicine, 4(3), 135(2018), https://doi.org/10.31254/jahm.2018.4308

5. G. Divya, S. Arulmozhi, L. Bodhankar Subhash, R. Mahadik Kakasaheb, Der Pharma Chemica, 6(5), 172(2014).

6. K. G. Singh, S. Sonia, N. Konsoor, International Journal of Pharmaceutical Science and Research, 9(8), 3543(2018), https://doi.org/10.13040/IJPSR.0975-8232.9(8).3543-51

7. V. M. Jadhav, R.M. Thorat, V.J Kadam, N.S. Sathe, Journal of Pharmacy Research, 2(8), 1220(2009).

8. S.I. Zubairi, N.S. Jaies, Malaysian Journal of Analytical Sciences, 18(2), 260(2014).

9. M Govindappa, Journal of Diabetes and Metabolism, 6(7), 1000565(2015), https://doi.org/10.4172/2155-6156.1000565

10. Z. Izadi, H. Zarei, American Journal of Plant Sciences, 5(13), 534(2012), https://doi.org/10.4236/ajps.2014.513197

11. S. Patel, M. Adhav, Journal of Pharmacognosy and Phytochemistry, 5(3), 93(2016).

12. D. Garg, A. Shaikh, A. Muley, T. Marar. Free Radicals and Antioxidants, 2(3),41(2012), https://doi.org/10.5530/ax.2012.3.6

13. V. Khristi and V. H. Patel, International Journal of Nutrition and Dietetics, 4(2), 105(2016), https://doi.org/10.17654/ND004020105 
RASĀYAN J. Chem.

Vol. 14 | No. 4 |2279-2284| October- December | 2021

14. A. A. Siddiqui, S. M. Wani, R. Rajesh and V. Alagarsamy, Indian Journal of Pharmaceutical Sciences, 68(1), 127(2006), https://doi.org/10.4103/0250-474X.22986

15. O.S Falade, M. A. Aderogba, O. Kehinde, B. A. Akinpelu, B.O. Oyedapo, S. R. Adewusi, Nigerian Journal of Natural Products and Medicine, 13, 120(2009), https://doi.org/10.4314/njnpm.v13i1.61609

16. R.M Vignesh, B.R.Nair, International Journal of Pharmaceutical Sciences and Research, 9(7), 2883(2018), https://doi.org/10.13040/IJPSR.0975-8232.9(7).2883-90

17. N.S. Ahmad Roslan, S.Zareen, N. Zamri, Journal of Materials Science Forum, 981, 296(2020), https://doi.org/10.4028/www.scientific.net/MSF.981.296

18. T. Sawidis, Journal of Flora, 193(3), 327(1998), https://doi.org/10.1016/s0367-2530(17)30855-1

19. M. P. Nguyen, Journal of Pharmaceutical Research International, 32(2), 12(2020), https://doi.org/10.9734/jpri/2020/v32i230397

20. P. Ruban, K. Gaja lakshmi, Asian Pacific Journal of Tropical Biomedicine, 2(5), 399(2012), https://doi.org/10.1016/S2221-1691(12)60064-1

[RJC-6459/2021] 